6. Kukes V. G., Habriev R. U., Palcev M. A. Molekuljarnye mehanizmy nezhelatelnyh jeffektov lekarstvennyh sredstv (monografija). M.:Russkij vrach; 2005: 137-153.

7. Romodanovsky D. P., Khapayev B. A., Ignatyev I. V., Kukes V. G., Karkishchenko V. N. Biomeditsina. - Biomedicine. 2010;2:33-37.

8. Sychev D. A., Ramenskaya G. V., Ignatyev I. V., Kukes V. G. Klinicheskaya farmakogenetika: uchebnoye posobiye. M.: GEOTAR-Media; 2007: 248 p.

9. Seredenin S. B. Lektsii po farmakogenetike. M.: MIA; 2004: $303 \mathrm{p}$.
10. Sychev D. A., Antonov I. M., Zagrebin S. V., Gasanov N. A., Kukes V. G. Racionalnaja Farmakoterapija v Kardiologii. - Rational Pharmacotherapy in Cardiology. 2007;2:59-66.

11. Sychev D. A., Stasyak Ye. V., Ignatyev I. V., Bulytova Yu. M., Ramenskaya G. V., Kukes V. G. Klinicheskaya farmakologiya I terapiya. - Clinical pharmacology and therapeutics. 2005;14(4):60-63.

12. Jakovleva N. V., Baturin V. A. Kardiovaskuljarnaja terapija i profilaktika. - Cardiovascular Therapy and Prevention. $2008 ; 7(6): 427-527$

About authors:

Baturin Vladimir Alexandrovich, Professor, Doctor of Medical Science; Head of Department for Clinical Pharmacology with Course of Post-Graduate and Additional Training, Stavropol State Medical University, Russia;

tel.: +7(8652)713466; e-mail: v_baturin@mail.ru

Tsarukyan Anna Akopovna, Assistant Lecturer; Department for Clinical Pharmacology with Course of Post-Graduate and Additional Training, Stavropol State Medical University, Russia;

tel.: +7(8652)713466; +79054901856; e-mail: a-tsarukyan@mail.ru

(C) Rogova L. N., Shesternina N. V., 2015

UDC 616.33-002.44:612.015.1:546.46

DOI - http://dx.doi.org/10.14300/mnnc.2015.10040

ISSN - 2073-8137

\title{
GELATINASE B AND MAGNESIUM IN THE DEVELOPMENT OF EXPERIMENTAL GASTRIC ULCER
}

\author{
Rogova L. N., Shesternina N. V. \\ Volgograd State Medical University, Volgograd, Russian Federation
РОАЬ ЖЕААТИНАЗЫ В И МАГНИЯ В ФОРМИРОВАНИИ ЭКСПЕРИМЕНТААЬНОЙ ЯЗВЫ ЖЕАУАКА

\author{
^. Н. Рогова, Н. В. Шестернина

\begin{abstract}
ВолгограАский госУАарственныЙ МеАицинский Университет, ВолгограА, Российская ФеАерация
\end{abstract}

Purpose of study was to determine the specific number and expression activity of gelatinase B-positive cells in the ulcerous defect, and the magnesium levels in the concentrated red cells obtained from various locations in rats with experimental acetate gastric ulcer. The experiment was performed on 18 white Wistar rats. The study of the specific number and gelatinase B expression activity was done through immunohistochemistry (Novocastra, NCL-MMP9, for the paraffin blocks, working dilution 1:40); the content of magnesium in red blood cells through the reaction with titan yellow. The study allows concluding that in the site of experimental ulcerous defect there is an increase in the number and the expression activity of gelatinase B-positive cells in the surface epithelium, with even a higher degree of increase in the gastric LPS (cellular component) against lowered magnesium levels in the concentrated red cells.

Key words: experimental acetate gastric ulcer, gelatinase $B$, magnesium

Цель исследования состояла в изучении удельного числа и активности экспрессии желатиназы B-позитивных клеток в тканях язвенного дефекта и уровня магния в эритроцитарной массе крови из разных регионов у крыс с экспериментальной ацетатной язвой желудка. Эксперименты выполнены на 18 белых крысах линии Вистар. Исследование удельного числа и интенсивности желатиназы В было проведено иммуногистохимическим методом («Novocastra», NCL-MMP9, для парафиновых блоков, рабочее разведение 1:40); содержание магния в эритроцитах - по реакции с титановым желтым. Проведенное исследование позволяет сделать заключение, что в зоне экспериментального язвенного дефекта увеличивается число и интенсивность экспрессии желатиназы В-позитивных клеток в покровном эпителии и еще в большей степени в СПСО (клеточный компонент) на фоне снижения содержания магния в эритроцитарной массе.

Ключевые слова: экспериментальная ацетатная язва желудка, желатиназа В, магний 


\section{$\mathrm{T}$} he etiological agent is known to affect the balance between factors of aggression and protective mechanisms, which leads to the development of ulcer in the gastrointestinal tract (GIT). Consistently high stomach acid levels, hyperactivation of pepsinogens and free radicals, duodenogastric reflux - all these are commonly known as factors of aggression. Ulcerative defect in the stomach and duodenum is a site of acute or chronic inflammation depending on the provoking etiological agent [2, $3,7]$. The acute-phase response area sees the destruction of extracellular matrix with matrix metalloproteinases: collagenases, gelatinases, stromielinases, which is followed with restoration of the damaged structures [8]. In particular, in the area of inflammation metalloproteinases $-3,-7$ and -9 get activated, which destroy intracellular structures and contribute to the cytokinemediated activation of growth factors, the latter stimulating proliferative processes. Similar change must take place in the ulcerated tissues of the GTI in case of peptic ulcer, which are chronic inflammatory lesion. An important role in matrix metalloproteinases (MMPs) activation resides in free radicals and cytokines. There is evidence available currently proving that magnesium deficiency confers activation of MMPs [12].

Purpose: to investigate the specific number and expression activity of gelatinase B-positive cells in the ulcerous defect, as well as the magnesium levels in the concentrated red cells obtained from different locations in rats with experimental acetate gastric ulcer (EAGU).

Material and Methods. The experiment was run on 18 white Wistar rats of both sexes weighing $198 \pm 3.8 \mathrm{~g}$, kept on a standard diet. All the animals had their blood levels of magnesium detected and underwent immunohistochemical study in the ulcerous defect area. The animals were divided into three groups: Group I of intact animals (6 rats); Group II consisted of 6 rats that had acetate ulcer simulated in the pyloric part of the stomach (S. Okabe method; 2005) under Nembutal anesthesia (30 mg/kg) [6]. Group III (control) included 6 rats that were subjected to the same intervention as Group II yet without any stomach wall lesion.

Initially, prior to the model development, blood from the subclavian vein was taken. The animals were discharged from the experiment 7 days after the simulation, with the samples to be drawn further - blood from subclavian and portal veins, lymph from the common intestinal lymphatic duct, and gastric tissues (pyloric part of the stomach) for the immunohistochemical test.

The morphological assessment of the ulcerous defect was done after 7 days of experimental simulation of EAGU. Gastric tissues bearing signs of ulcerous lesion were taken for the research. The area of the ulcer was assessed through planimetry. Fixation of the specimens, dehydration, prepa- ration of paraffin sections and hematoxylin-eosin staining were performed based on the conventional method [5]. The morphological changes and the number of cells in the inflammatory infiltrates were evaluated in the specimens through a visual analog scale within the lamina propria of the stomach (LPS) and its submucous layer (SL) [1].

To study the specific number and expression rates of gelatinase $B$ immunohistochemistry was performed according to the standard procedures employing the Novocastra antibodies (NCL-MMP9, for the paraffin blocks, working dilution 1:40). In the preparations of the surface epithelium and lamina propria of the gastric mucosa (cellular component) the specific number (\%) of positively stained cells in 5 randomly selected fields of microscope $(\geq 500$ cells) was evaluated (400-fold magnification). The staining reaction was considered negative ( 0 points); weak (1 point); medium (2 points), and marked (3 points).

The magnesium levels in plasma and lymph were determined with a special set (Lachema), while the content of magnesium in red blood cells was judged based on the reaction with titan yellow [4].

The mean values under normal distribution were expressed as $M \pm m$, the statistical significance of the differences was assessed through Student's t-test; if the distribution deviated from the normal - as the median (Me), 25/75 percentile, the significance of the differences was assessed using the Wilcoxon test under the significance level of $Q$ $<0.05$. The outcomes were processed through the variation statistics method using the standard Data Analysis Tools of Excel.

Results and Discussion. Seven days after the start of the simulation a typical ulcer developed, usually crateriform, with a granulation bank, oedema, hyperemia, and hemorrhages in the mucosa with an area of $30.95 \pm 6.7 \mathrm{~mm}^{2}$. Given that, the EAGU revealed the following morphological parameters (measure unit - points): the depth of the ulcerous defect $1(1 ; 2)$; fibrinoid necrosis $1(0 ; 1)$; granulation tissue $1(0,5 ; 1)$, and the vascular component of the SL $2(1 ; 2)$ (Me $(25 / 75$ percentile)).

Seven days after the simulation was started, the control group showed no change in neutrophil, macrophage, lymphocyte, plasmocyte and eosinophil infiltration in the LPS and SL, if compared with the initial status.

In case of EAGU, 7 days after the start of the simulation, the number of plasmocytes and eosinophils in the LPS did not differ from the control values equaling $1(1 ; 1.75)$ and $2(1.25 ; 2)$, respectively, compared with $0(0 ; 0)$ and $1(1 ; 1,75)$ points in controls. Infiltration with macrophages, lymphocytes and neutrophils increased reaching $2(1.25 ; 2.75), 2(1.25 ; 2.75)$, and $1.5(1 ; 2)$, respectively, compared with $0.5(0 ; 1), 1(0.25 ; 1)$, and $0.5(0 ; 1)$ points in controls $(Q<0.05)$.

In case of EAGU, 7 days after the start of the simulation, the number of neutrophils, 
macrophages, eosinophils and plasmocytes in the SL did not reveal any statistically significant change constituting $1(1 ; 1.75), 1.5(1 ; 2), 1,5(1 ; 2)$, and $1(1 ; 1)$, respectively, compared to $1(0 ; 1), 2(1.25$; $2), 1(1 ; 1)$, and $0,5(0 ; 1)$ points in the control group. The lymphocyte infiltration went up to 2.5 $(2 ; 3)$ compared with $1(1 ; 1.75)$ points in controls $(\mathrm{Q}<0.05)$.

The specific number and activity of expression in gelatinase B-positive cells in the gastric tissues of the intact animals was prominent neither in the number nor in the expression activity of the antigen-positive cells. The control group showed some activation of gelatinase $B$, both in the surface epithelium and in the LPS (cellular component), which was not statistically significant. In case of a developed EAGU, the surface epithelium of the stomach shows a significantly higher expression against a tendency for an increase in the specific number of gelatinase B-positive cells. Besides, there was a simultaneous increase detected in the gelatinase B-positive cells in the LPS (cellular component) $(Q<0.05)$, while during that the LPS (cellular component) revealed a more pronounced increase in the number of gelatinase $B$-positive cells at their top high expression activity (Table 1).

Table 1

Specific number and expression activity of gelatinase B-positive cells in case of experimental acetate gastric ulcer, 7 days after start of simulation [25/75 percentile]

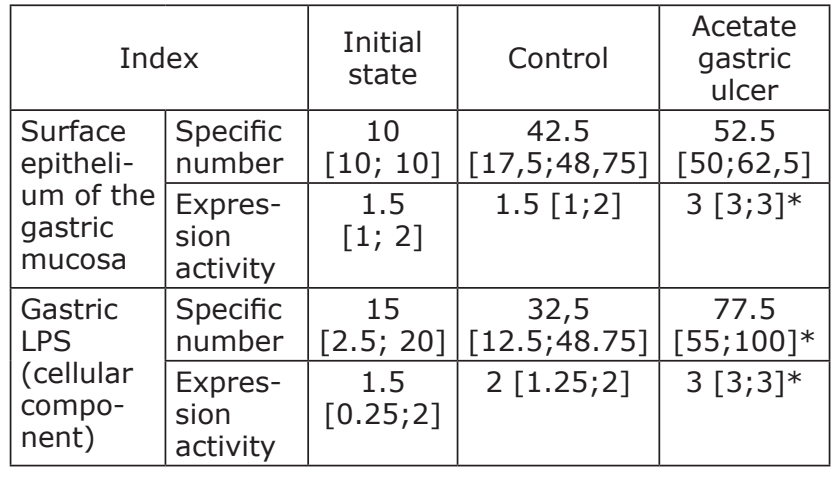

*- significance of the differences between the controls and in $\mathrm{EAGU}, \mathrm{P}<0.05$

On Day 7, th in the animals with EAGU the magnesium levels found in the concentrated red cells in the blood taken from subclavian vein was 1.36 lower if compared to the control group $(p<0.05)$. At the same time there appeared moderate negative correlation between the area of the ulcerous defect and the levels of endoglobular magnesium in the subclavian vein in the initial state $(r=-0.4)$, while the same index could be described as strong in case of a fully developed EAGU ( $r=-0.89)$. However, the level of this element in the blood taken from the portal vein remained almost unchanged. In case of formed gastric ulcer the magnesium concentrations in the plasma obtained from the subclavian vein blood, portal vein blood, and lymph did not change significantly when compared with the control levels (Table 2).
Table 2

Magnesium levels in concentrated red cells and blood plasma $(\mathrm{mmol} / \mathrm{l})$ in rats with experimental acetate gastric ulcer, 7 days after start of simulation $(\mathbf{M} \pm \mathbf{m})$

\begin{tabular}{|l|c|c|c|}
\hline \multicolumn{1}{|c|}{ Index } & $\begin{array}{c}\text { Initial } \\
\text { state }\end{array}$ & Control & $\begin{array}{c}\text { Acetate } \\
\text { gastric ulcer }\end{array}$ \\
\hline $\begin{array}{l}\text { Subclavian vein } \\
\text { (concentrated red } \\
\text { cells), (mmol/l) }\end{array}$ & $1.52 \pm 0.089$ & $1.8 \pm 0.105^{* *}$ & $1.32 \pm 0.082^{* *}$ \\
\hline $\begin{array}{l}\text { Portal vein (con- } \\
\text { centrated red } \\
\text { cells), (mmol/l) }\end{array}$ & $1.48 \pm 0.13$ & $1.65 \pm 0.11$ & $1.69 \pm 0.105$ \\
\hline $\begin{array}{l}\text { Subclavian vein } \\
\text { (plasma), (mmol/l) }\end{array}$ & $0.981 \pm 0.015$ & $0.917 \pm 0.011^{*}$ & $0.914 \pm 0.026^{* *}$ \\
\hline $\begin{array}{l}\text { Portal vein (plas- } \\
\text { ma), (mmol/l) }\end{array}$ & $1.02 \pm 0.013$ & $0.884 \pm 0.006^{* * *}$ & $0.923 \pm 0.02 * * *$ \\
\hline Lymph, (mmol/l) & $0.72 \pm 0.004$ & $0.71 \pm 0.018$ & $0.69 \pm 0.012$ \\
\hline
\end{tabular}

In relation to the initial state: ${ }^{*}-p<0.05 ;{ }^{* *}-p<0.01$; $* * *-p<0.001$

The outcomes suggest that in the initial state a higher activity of gelatinase B can be seen in the LPS (cellular component). In the control series, at a very moderate impact on the serous membrane of the GIT, there is an increase in the number of the cells expressing gelatinase B in the LPS (cellular component), yet, even more it is in the surface epithelium of the gastric mucosa where the rate of stress renewal in the mucosa must be on the up. In case of a formed EAGU, an increase is observed in the specific number of gelatinase B-positive cells, both in the surface epithelium of the gastric mucosa and in the gastric LPS (cellular component). A high activity of gelatinase $B$ expression in different locations of the gastric mucosa seems to reflect the strain in destructive and inflammatory, destructive and proliferative processes occurring in the tissues during the development of an ulcer.

Proliferation mechanisms have been proven to be energy-consuming. Intracellular magnesium has a significant role in the activation of factors entrained into the production and consumption of energy [9, 11]. Its accumulation in the cell typically results from the development of specific TRAMP-6 and TRAMP-7 magnesium channels [10]. The decrease in erythrocyte magnesium levels, which is typical of ulcer development, must be due to redistribution processes in favor of the damaged tissues. This fact could be confirmed indirectly through a slight decrease in the concentration of magnesium in the lymph flowing from the intercellular spaces in the GIT tissues.

Gromova O. A. et al. (2008) suggest that magnesium deficiency disturbs the metabolism of connective tissue by activating enzymes like hyaluronidase, transglutaminase, metalloproteinase, etc. [12]. Our results also suggest a negative correlation between the content of intracellular magnesium and the activity of gelatinase B expression in the LPS (cellular component) and the surface epithelium.

Conclusions. The study described above offers sufficient evidence to conclude that in the site of experimental ulcerous defect there is an increase in the number and expression activity of gelatinase B-positive cells of the surface epithelium, and even more - in the gastric LPS (cellular component), against reduced magnesium levels in the concentrated red cells. 
References

1. Arunin L.I., Kapuller L.L., Isakov V.A. Morphological diagnosis of diseases of the stomach and intestines. Triada-X, 1998:496p

2. Bacon C., Ming-Qing Du, Dogan A. Mucosa-associated lymphoid tissue (MALT) lymphoma: a practical guide for pathologists. J. Clin. Pathol. 2007;60:361-372.

3. Ivashkin V.T. Meditsinskii Vestnik Severnogo Kavkaza. Medical News of North Caucasus. 2006;19(362):9-10.

4. Kamishnikov V.S. Handbook of clinical and biochemical research laboratory diagnostics. Moscow: MEDpressinform. 2004.

5. Korzhevsky D.E. Basics of histologic techniques. Moscow: Meditsina, 2010:234p.

6. Okabe S., Amagase K. An overview of acetic acid ulcer models. The history and state of the art of peptic ulcer research. Biol. Pharm. Bull. 2005;8(28):1321-1341.
7. Okorokov A.N. Diagnosis of diseases of the internal organs: Volume 1. Diagnosis of diseases of the digestive system. Moscow: Med.lit. 2002:560p.

8. Parks W.C., Wilson C.L., López-Boado Y.S. Matrix metalloproteinases as modulators of inflammation and innate immunity. Nature Reviews Immunology. 2004;8(4):617-629.

9. Povetkina V.N., Rogova L.N. Vestnik novich meditsinskich technologiy. - Bulletin of new medical technologies. 2011;2(18):83-86.

10. Rubin H. The logic of the Membrane, Magnesium, Mitosis (MMM) model for the regulation of animal cell proliferation. Science. 2003;261:1280-1281.

11. Staravoitov V.A., Rogova L.N., Stacenko M.E. Vestnik Rossiiskogo universiteta druzhbi narodov (Medicina) Bulletin of the Russian Peoples' Friendship University (medicine series). 2008;7:532-534.

12. Troshin I.Yu., Gromova O.A. Kardiologiya - Cardiology. 2008; 10:14-21.

About authors:

Rogova Lyudmila Nikolaevna, Professor, Doctor of Medical Science; Head of Department for Pathophysiology, Clinical Pathophysiology, Kuban State Medical University, Russia; tel.: +7(8442)385364

Shesternina Natalya Vladimirovna, Candidate of Medical Science; Assistant Lecturer, Department for Pathophysiology Clinical Pathophysiology, Kuban State Medical University, Russia; tel. : +7(8442)385364

(c) Group of authors, 2015

UDC - 616.36-002:615.015

DOI - http://dx.doi.org/10.14300/mnnc.2015.10041

ISSN - 2073-8137

\title{
POSSIBILITIES OF ORIGINAL «BICYCLOL» MEDICINE IN THERAPY OF CHRONIC HEPATITIS C
}

Geyvandova N. I. ${ }^{1}$, Lioznov D. A. ${ }^{2}$, Morozov V. G. ${ }^{3}$, Yagoda A. V. ${ }^{1}$, Koroy P. V. ${ }^{1}$, Nikolaenko S. L. ${ }^{2}$, Glazkova E. Ja. ${ }^{3}$, Liu G. T. ${ }^{4}$, Han Ji. ${ }^{5}$

'Stavropol State Medical University, Stavropol, Russian Federation

${ }^{2}$ Pavlov First Saint Petersburg State Medical University, Saint Petersburg, Russian Federation

${ }^{3}$ Medical company uHepatologistı, Samara, Russian Federation

${ }^{4}$ Institute of Materia Medica, Chinese Academy of Medical Sciences, Beijing, China

${ }^{5}$ Xijing Hospital of Digestive Diseases, The Fourth Military Medical University, Xijing, China

\section{ВОЗМОЖНОСТИ ОРИГИНААЬНОГО ПРЕПАРАТА „БИЦИКАОА» В ТЕРАПИИ ХРОНИЧЕСКОГО ГЕПАТИТА С}

\author{
Н. И. Гейванаова ${ }^{1}$, А. А. Аиознов ${ }^{2}$, В. Г. Морозов ${ }^{3}$, А. В. ЯгоАа ${ }^{1}$, П. В. Корой ${ }^{1}$, \\ С. А. Николаенко ${ }^{2}$, Е. Я. ГАазкова ${ }^{3}$, Г. Т. $А и y^{4}$, И. Хан ${ }^{5}$
}

'Ставропольский госуАарственный меАицинский университет,
Ставрополь, Российская ФеАерация

${ }^{2}$ Первый Санкт-Петербургский госуАарственный меАицинский университет имени И.П. Павлова, Санкт-Петербург, Российская ФеАерация

${ }^{3}$ МК «Гепатологи, Самара, Российская Фелерация

${ }^{4}$ Институт "Материа МеАика" Китайской акаАемии МеАицинских наук,

Пекин, Китайская Народная Республика

${ }^{5}$ КсиАжинг госпиталь болезней органов пищеварения,

Четвертый Военный МеАицинский университет, КсиАжинг, Китайская Народная Республика

53 patients with chronic hepatitis $\mathrm{C}$ were treated in multicenter clinical trial: 26 female and 27 male, 23 have received antiviral therapy in a past. Inclusion criteria were follows: ALT activity $\geq 1.5$ ULN, absence of signs of liver cirrhosis decompensation and hepatocellular cancer. Bicyclol ${ }^{\circledR}$ medicine (Beijing Union Pharmaceutical Factory, PRC) was administered in a daily dose $150 \mathrm{mg}$ during 12 weeks. A primary efficacy criterion was ALT activity. There were decrease in ALT, AST activity and bilirubin level in patients who received Bicyclol ${ }^{\circledR}$, enhance in asthenic-vegetative syndrome as well. In the placebo group there were 